University of Nebraska - Lincoln

DigitalCommons@University of Nebraska - Lincoln

Agronomy \& Horticulture -- Faculty Publications

Agronomy and Horticulture Department

2-1-1988

\title{
Photographic Technique for Grass Seedling Root Systems
}

P. R. Newman

Research Dep., U,S. Sugar Corp., Clewiston, FL

Lowell E. Moser

University of Nebraska-Lincoln, Imoser1@unl.edu

Follow this and additional works at: https://digitalcommons.unl.edu/agronomyfacpub

Part of the Plant Sciences Commons

Newman, P. R. and Moser, Lowell E., "Photographic Technique for Grass Seedling Root Systems" (1988). Agronomy \& Horticulture -- Faculty Publications. 85.

https://digitalcommons.unl.edu/agronomyfacpub/85

This Article is brought to you for free and open access by the Agronomy and Horticulture Department at DigitalCommons@University of Nebraska - Lincoln. It has been accepted for inclusion in Agronomy \& Horticulture -Faculty Publications by an authorized administrator of DigitalCommons@University of Nebraska - Lincoln. 


\section{PHOTOGRAPHIC TECHNIQUE FOR GRASS SEEDLING ROOT SYSTEMS}

\author{
P. R. NEWMAN AND L. E. MOSER*
}

\section{Abstract}

In descriptive studies of seedling root morphology a seedling root system must be clearly visible to develop clear photographs. A technique for photographing grass seedling root systems has been developed for morphological-developmental studies. Seedlings were carefully washed from the growing media and placed in a thin tank with two glass sides filled with water and with a grid pattern on one side. The lower stem and root system were immersed in the water where the natural buoyancy of the root system in water allowed the root to spread out, which improved visibility. Photographs were taken of the illuminated seedling root system and grid pattern with a camera positioned on the shaded side of the tank. Detailed diagrams of the tank and placement of the camera, lights, and shades are presented. This technique produced high-quality photographs of grass seedling root systems that show seedling root morphology clearly.

Additional Index Words: Seedling growth, Primary root system, Root pattern.

P.R. Newman, Research Dep., U.S. Sugar Corp., Clewiston, FL 33440; and L.E. Moser, Dep. of Agronomy, Univ. of Nebraska, Lincoln, NE 68583. Contribution from the Dep. of Agronomy, Univ. of Nebraska. Paper no. 8245. Received 10 Feb. 1987. *Corresponding author.

Published in Agron. J. 80:548-549 (1988).

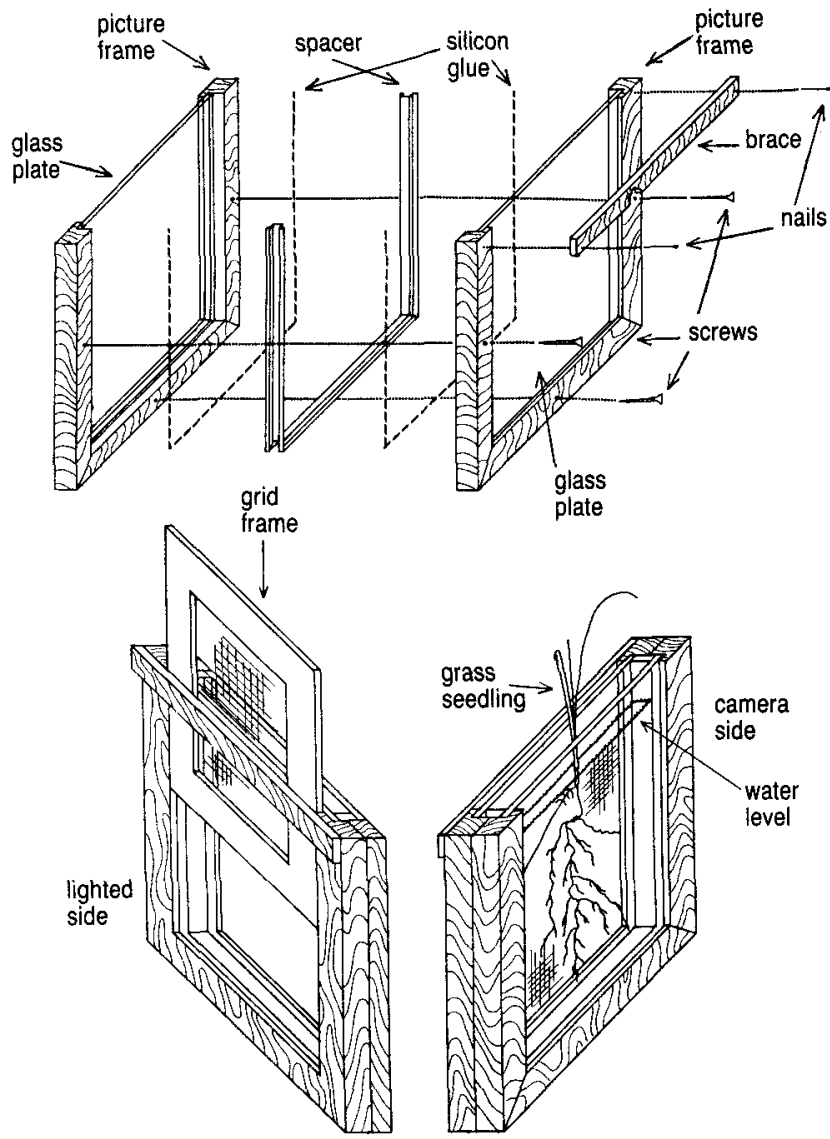

Fig. 1. Construction details of the thin glass tank showing positioning of the grid frame and the grass seedling.
DESCRIPTIVE studies of seedling root morphology often fail to show live specimens that retain their natural form. Photographs of seedling root systems on contrasting color background have been used. Hyder et al. (1971) showed seedling morphology of blue grama [Bouteloua gracilis (H.B.K.) Lag. ex Steud.] and crested wheatgrass [Agropyron desertorum (Fisch. ex Link) Schult.] by spray painting the whole of the seedlings black then photographing them on a white background. Sommer (1936), who photographed plant root systems in a tray under water, was the only researcher found in the literature to use water as an aid in photographing root systems. Our objective was to develop a photographic technique that shows seedling root system in a diffused form so the morphological form was clearly visible.

\section{Methods}

A thin tank with two glass sides was constructed from two 30 - by $25-\mathrm{cm}$ picture frames fastened back-to-back on three sides with screws (Fig. 1). A plastic spacer was inserted between the glass plates to leave $1 \mathrm{~cm}$ between the two glass sides. General Electric Glue and Seal ${ }^{1}$ clear household silicon glue (General Electric Co., Wilmington, MA) was used to seal the tank. A brace was attached to the outside near the open end of the tank to add strength.

The seedlings were washed from the growing media, taking care not to break roots. A clean root system was essential to keep the water in the tank clear. Brief, gentle washing of the root system in soapy water removed any remaining fine clay particles. The lower stem and root system were immersed into the water keeping the leaf blades above the water level inside the tank (Fig. 1). Lighter seedlings were held in place by the adhesive force of water between the leaf blade and the surface of the glass. Heavier seedlings were taped to a support structure above the tank. Natural buoyancy in the water allowed the root system to spread out, which improved visibility of various components. Four tungsten (250W) photographic lamps on flexible support tubing were positioned $16 \mathrm{~cm}$ from the back edge of the tank at $45^{\circ}$ angles

\footnotetext{
' Use of a commercial product does not constitute endorsement by the University of Nebraska-Lincoln.
}

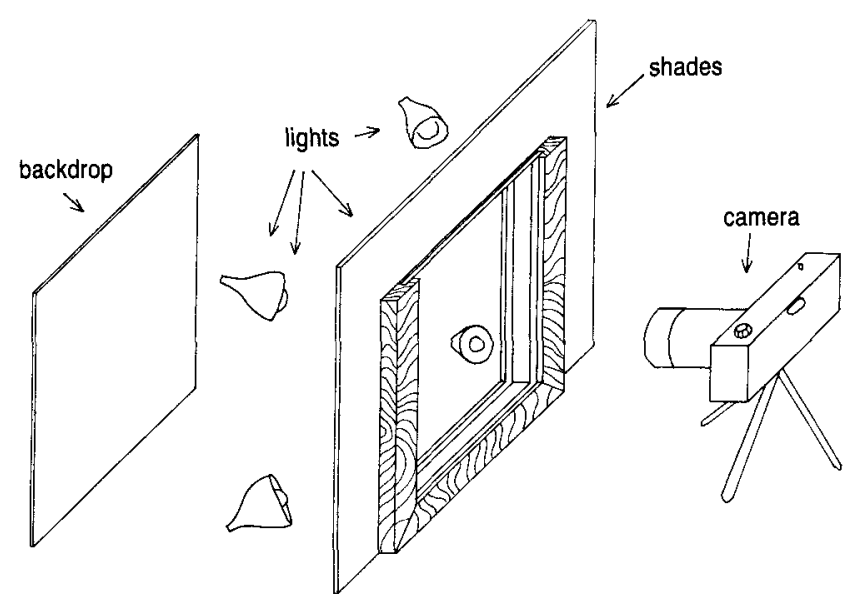

Fig. 2. Placement of lights, camera, shades, and backdrop around the thin glass tank. 


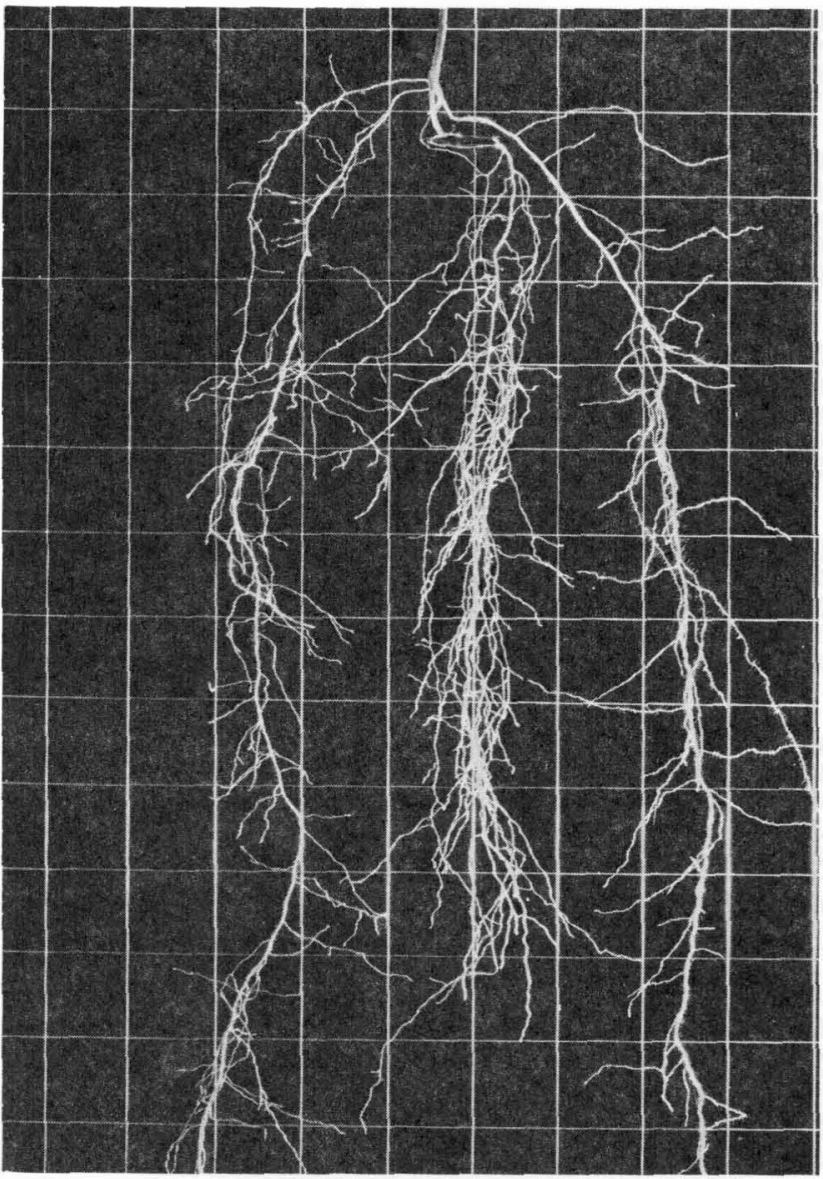

Fig. 3. Smooth bromegrass (Bromus inermis Leyss.) seedling $30 \mathrm{~d}$ from planting photographed in the glass tank with a 50-mm macro lens and Kodak Panatomic-X film at $1 / 4 \mathrm{~s}, 8 \mathrm{f}$-stop. Each square equals $1 \mathrm{~cm}^{2}$.

(Fig. 2). Black cardboard shades, $10 \mathrm{~cm}$ wide, were attached to each side of the tank to exclude light except the light reflected from the seedling root system (Fig. 2). A 35-mm camera was mounted on a tripod in front of the tank, and a black background was mounted $70 \mathrm{~cm}$ from the tank on the opposite side to exclude any extraneous light (Fig. 2). A $1-\mathrm{cm}^{2}$ grid pattern, to show size in the photographs, was constructed of DuPont Stren ${ }^{1}$ clear-blue fluorescent monofilament fishing line (DuPont Co., Wilmington, DE) and cellophane taped onto a cardboard frame. The heat from the photographic lamps caused the monofilament fishing line to shrink tight, although it loosened each time it cooled. This grid system allowed relative size of the root system to be visualized regardless of the size of the photograph. A larger diameter filament could be added at every fifth or tenth line to faciliate rapid size evaluation of a large root system. The grid frame was placed on the outside of the lighted side of the tank opposite to the camera, with the line against the glass (Fig. 1). A $50-\mathrm{mm}$ macro lens was used. The shutter speed on the camera was set at $1 / 15 \mathrm{~s}$. The lens aperture was set according to the camera's light meter, then advanced $1 / 2$ to the $1 f$-stop. Color slides were taken with a film that was compatible to the light source. Black and white prints made using this method with Kodak Panatomic $X^{1}$ film (Eastman Kodak Co., Rochester, NY) were also excellent (Fig. 3). This technique produced high-quality photographs of grass seedling root systems that showed seedling root morphology clearly in a diffused form.

\section{References}

Hyder, D.N., A.C. Everson, and R.E. Bement. 1971. Seedling morphology and seedling failures with blue grama. J. Range Manage. 24:287-292.

Sommer, A.L. 1936. The relationship of the phosphate concentration of solution cultures to the type and size of root systems and the time of maturity of certain plants. J. Agric. Res. 52:133-148.

\section{COMPARING SEALED CHAMBER DIGESTION WITH OTHER DIGESTION METHODS USED FOR PLANT TISSUE ANALYSIS}

\section{L. ANDERSON* AND L. J. HENDERSON}

\begin{abstract}
A sealed chamber digestion (SCD) method was developed as a rapid and simple means of tissue digestion for micro-samples. The objective of this study was to test SCD against other digestion methods used for plant-tissue analyses. Sealed chamber digestion, dry ash combustion, nitric/perchloric acid wet ash digestion, and sulfuric acid/hydrogen peroxide wet ash digestion methods were evaluated for efficacy of organic matter destruction for elemental analysis of plant tissues. Eight tissue standards were collected from the National Bureau of Standards, the University of Georgia, and the Everglades Research and Education Center, University of Florida. The objective of this study was to compare the previously reported SCD method with other digestion methods used for plant tissue analyses. With the exception of analysis for $\mathrm{Al}$ and $\mathrm{Fe}$, comparison of methods of analyses indicated that SCD did not differ greatly from other digestion methods. Digestion method efficacy, as determined by nutrient analysis, appeared to reflect the plant material digestibility and digestion method. The advantages and disadvantages of the methods studied are discussed.
\end{abstract}

Additional Index Words: Dry ash combustion, Perchloric/nitric acid digestion, Plant analysis, Plant tissue digestion, Pressure dissolution, Sulfuric acid/hydrogen peroxide digestion.

$\mathrm{E}$ XAMPLES of closed chamber organic matter destruction techniques that yield good chemical determinations are: the pressure dissolution of plant materials in polyethylene bottles at $80^{\circ} \mathrm{C}$ using $\mathrm{HCl}$ (Kuennen et al., 1982), sludge digestion at $125^{\circ} \mathrm{C}$ in sealed ampules using nitric acid (Sung et al., 1984), and wood digestion in a Teflon bomb at $125^{\circ} \mathrm{C}$ using hydrogen peroxide (Matusiewicz and Barnes, 1985). Digestion of plant samples in closed vessels also has been successfully accomplished using microwave energy (Kingston and Jassie, 1986; Lamothe et al., 1986). Sealed chamber digestion (SCD) for tissue analyses was recently described by Anderson and Henderson (1986) and utilizes perchloric acid and hydrogen peroxide under low temperature and solution volumes.

D.L. Anderson, Univ. of Florida, Everglades Res. and Educ. Ctr., Belle Glade, FL 33430; and L.J. Henderson, United States Sugar Corp., Clewiston, FL 33440. Contribution from the Univ. of Florida, Inst. of Food and Agric. Sci. Agric. Exp. Stn. Journal Series no. 7959. Received 24 Aug. 1987. *Corresponding author.

Published in Agron. J. 80:549-552 (1988). 